\title{
Distribution of Papaya ringspot virus and Papaya mosaic virus in Papaya Plants (Carica papaya) in Mexico
}

J. C. Noa-Carrazana, Departamento de Ing. Genética, Cinvestav, Km. 9.6 Lib. Nte. Carr. Irapuato-León, 36500, A. P. 629, Irapuato, Gto. Mexico; D. González-de-León, Paseo del Atardecer 360, Irapuato, Gto. 36670, Mexico; B. S. Ruiz-Castro, Departamento de Ing. Genética, Cinvestav, Km. 9.6 Lib. Nte. Carr. Irapuato-León, 36500, A. P. 629, Irapuato, Gto. Mexico; D. Piñero, Departamento de Ecología Evolutiva, Instituto de Ecología, UNAM, Mexico; and L. Silva-Rosales, Departamento de Ing. Genética, Cinvestav, Km. 9.6 Lib. Nte. Carr. Irapuato-León, 36500, A. P. 629, Irapuato, Gto. Mexico

\section{ABSTRACT}

Noa-Carrazana, J. C., González-de-León, D., Ruiz-Castro, B. S., Piñero, D., and Silva-Rosales, L. 2006. Distribution of Papaya ringspot virus and Papaya mosaic virus in papaya plants (Carica papaya) in Mexico. Plant Dis. 90:1004-1011.

We report the results of a survey for the presence of Papaya ringspot virus (PRSV) along the coasts of the Gulf of Mexico and the Pacific Ocean, in 15 federal states of Mexico that account for over $98 \%$ of the national papaya production. More than 80 locations were visited in 58 counties. Out of a total of 267 papaya leaf samples, 157 tested positive for PRSV. We tested for the presence of three other viruses because of the occurrence of severe, atypical symptoms in plantations. Only Papaya mosaic virus (PapMV) was detected. PRSV was present in every county. PapMV was less frequent, but its overall distribution was almost identical. PRSV and PapMV occurred in single or mixed infections of papaya and other host species that could function as virus reservoirs. We investigated the diversity of the coat protein (CP) sequences of 36 PRSV isolates. The amino acid sequence divergence among all isolates ranged from 0.4 to $9.9 \%$, and was comparable to that found in other regions of the world. In contrast to most of these world regions, there is a clear correlation between $\mathrm{CP}$ sequence variation and the geographical origins of the virus isolates.

Additional keywords: potexvirus, potyvirus, sequence diversity

As with many other crops, virus diseases in papaya (Carica papaya L.) limit fruit production in most parts of the world (Asia, Africa, Australia, South and North America, and the Caribbean). The viruses most often reported in this crop are Papaya ringspot virus (PRSV), a potyvirus $(20,32$, 52,53), Papaya mosaic virus (PapMV), a potexvirus $(21,33,35,36)$, Papaya apical necrosis virus (PANV), a rhabdovirus (23), Tobacco ringspot virus (TRSV), a nepovirus $(10,26)$, and Papaya leaf distortion mosaic virus, a potyvirus (PLDMV) (25).

PRSV was first detected in Mexico in 1975, where it caused severe damage in the main papaya production states with crop losses of up to $85 \%$ (48). PRSV is a member of the genus Potyvirus (32) in the

Corresponding author: L. Silva-Rosales

E-mail: 1silva@ira.cinvestav.mx

*The $\boldsymbol{e}$-Xtra logo stands for "electronic extra" and indicates the HTML abstract available on-line contains an expanded version of Table 2 with material not included in the print edition.

Accepted for publication 27 February 2006.

DOI: 10.1094/PD-90-1004

(C) 2006 The American Phytopathological Society
Potyviridae family, with filamentous particles from 700 to $900 \mathrm{~nm}(15,54)$ and RNA genomes of about 10,000 nucleotides. Molecular characterization of three Mexican PRSV strains and comparison of their coat protein $(\mathrm{CP})$ nucleotide sequences showed a closer relationship to American and Australian than to Asian isolates (45).

PapMV was first reported in Florida (USA) in 1962 (6), and has only been reported in Mexico recently (28), where it seems to be of little economic importance. It is a member of the genus Potexvirus within the Flexiviridae family (11). It is a 530-nm-long filamentous particle, with a positive sense single-stranded RNA genome comprising 6,656 nucleotides (excluding the $\operatorname{poly}(\mathrm{A})$ tail) with six open reading frames (46).

It is known that the simultaneous infection of higher plants by two or more viruses (mixed infections) is quite common, and papaya seems to be no exception. Indeed, there is one report regarding mixed infection in papaya plants, which involves PRSV and TRSV in Nigeria, although it occurs infrequently (in two plants out of 316 samples with symptoms of viral disease) (22). However, there are no reports of mixed infections in papaya plants with PRSV and PapMV. In mixed infections, a synergistic interaction between two independent viruses in the same host can occur; it is typically characterized by a dramatic increase in symptoms and by the accumulation of one of the two coinfecting viruses $(14,37,41,42,49,51)$. Many synergistic diseases involve a member of the genus Potyvirus as one of the infecting viruses $(1,4,9,31)$.

The papaya producing regions of Mexico are mostly concentrated along the coasts of both the Gulf of Mexico and the Pacific Ocean. These regions fall into vast physiographic or geomorphological zones that are separated by topographic barriers. One hypothesis tested on the basis of the distribution and preliminary molecular diversity data generated in this study is that PRSV diversity is partitioned according to broad geographic and papaya germplasm movement patterns. The value of this and other hypotheses pertaining to the present distribution of PRSV in Mexico is discussed and provides a solid starting point for our current in-depth study of the evolution and biological diversification of this virus in the American continent.

\section{MATERIALS AND METHODS}

Sample collection. A survey was conducted along the coasts of both the Gulf of Mexico and the Pacific Ocean, in 15 federal states of Mexico that account for over $98 \%$ of the national papaya production (Table 1) $(43,44)$. More than 80 locations were visited in 58 counties. Sample numbers in different locations mostly reflected the importance of each region in terms of production. Plants were sampled in commercial papaya fields, in adjacent fields, or in uncultivated areas where wild papaya plants could sometimes be found (mainly in the southeast of the country). Samples were collected over a period of 4 years (1997 to 2000). Leaf tissue samples were taken from papaya plants either showing systemic viral symptoms (yellowing, veinclearing, mosaic, and leaf distortion) or no symptoms. Sampling of papaya leaves depended on the severity of the disease across the plantation; a few samples of clearly affected plants were taken when disease levels were high, whereas both diseased and symptomless plants were 
sampled when levels were lower. Cucurbits and other weedy plant species that were present in the papaya fields at four locations were collected whenever they showed symptoms of viral infection. All collected samples were kept at $-70^{\circ} \mathrm{C}$. Table 2 summarizes information about all analyzed samples.

The papaya-producing regions visited during the collection trips can be classified in terms of broad, distinct, physiographic regions. In order to investigate any geographical patterns in the distribution of PRSV strains, we mapped the counties and locations of all analyzed samples onto both the political and the physiographic map available through the Mexican Institute of Statistics, Geography and Informatics (INEGI) (18). States and physiographic regions were assigned acronyms for reference in the text (Table 2, Fig. 1).

Virus detection (ELISA). Preliminary virus identification in each leaf sample was performed using standard double-antibody sandwich enzyme-linked immunosorbent assays (DAS-ELISA) with rabbit antiPRSV and anti-PapMV polyclonal sera (Agdia, Elkhart, IN, USA) (7). For each plant, a crude leaf extraction was made and replicate absorbance readings were taken. In eastern and southeastern regions, mixed infections with other papaya viruses were suspected because leaves with mild mosaic or other, unexpected symptoms such as stunting or apical stem necrosis were PRSV-ELISA negative. They were therefore assayed using ELISA for the presence of three other papaya viruses: PapMV (38), TRSV (22), and TSWV (16). In the case of PRSV, two types of positive control samples were used: one provided by the manufacturer and the other from a previously characterized isolate (45). For other viruses, the commercial control provided in the kit was used. Given that ELISA tests were not always unequivocal, more sensitive methods were also used. For PRSV, only $36 \%$ of all samples were tested with this method; more reliable reverse transcription-polymerase chain reaction (RTPCR) detection was performed on $87 \%$ of all samples (the other $13 \%$ were deemed positive on the basis of ELISA alone). The corresponding proportions for PapMV were: $19 \%$ by ELISA, $65 \%$ by RT-PCR, and $27 \%$ by Northern analysis. Finally, when the RT-PCR results were in doubt, samples were checked by Northern analysis ( $15 \%$ of all samples).

RT-PCR. Assays were conducted on total leaf RNA extracted according to published protocols $(24,39)$. Reverse transcription (RT) of RNA was carried out using 5 $\mu \mathrm{g}$ of total leaf RNA from healthy and infected plants, in a final reaction volume of $50 \mu \mathrm{l}$ and in the presence of $0.5 \mathrm{pmol} / \mu \mathrm{l}$ of the "downstream 3' primer". Thus, RNA was denatured at $70^{\circ} \mathrm{C}$, mixed with 10 units of MMLV reverse transcriptase (Promega), and incubated at $42^{\circ} \mathrm{C}$ for $1 \mathrm{~h}$.
Each of the resulting cDNA samples was amplified by PCR using $10 \mu$ lof the corresponding RT reaction, $2.5 \mathrm{U}$ Taq polymerase (BRL-Gibco), $250 \mu \mathrm{M}$ dNTPs each, and $0.5 \mathrm{pmol} / \mu \mathrm{l}$ of each of the $3^{\prime}$ downstream and $5^{\prime}$ upstream primers, in a final $50 \mu \mathrm{l}$ reaction volume. PCR amplifications were carried out in either a Perkin Elmer GeneAmp PCR System 2400 or a Genius Techne (Model FGEN05TP). The design of the PRSV and PapMV primers for RT-PCR of the CP gene was reported previously $(28,39)$. The conditions for PapMV PCR amplification were the following: $4 \mathrm{~min}$ at $94^{\circ} \mathrm{C}$, followed by 25 cycles each comprising $1 \mathrm{~min}$ at $94^{\circ} \mathrm{C}, 1$ min at $60^{\circ} \mathrm{C}$ (for PapMV), and $3 \mathrm{~min}$ at $72^{\circ} \mathrm{C}$. The reactions were ended with a final cycle of $7 \mathrm{~min}$ at $72^{\circ} \mathrm{C}$. Aliquots of 5 $\mu \mathrm{l}$ of RT-PCR amplified products were subjected to electrophoresis in $0.8 \%$ agarose gels to verify the presence and the correct size of the amplified products. RTPCR products were cloned in the vector contained in the pCR2.1 TOPO TA Cloning Kit (Invitrogen Co.) according to the manufacturer's instructions. One or two randomly selected clones of each of 33 isolates were sequenced in both directions, using an ABI Prism 377 DNA sequencer. A total of 47 sequences for PRSV CP were obtained. Three other isolates that had already been analyzed in previous work (45), were included for comparison.

Northern analysis. Five micrograms of total RNA was electrophoresed on denaturing $1.2 \%$ agarose- $6 \%$ formaldehyde gels and blotted onto nylon membranes (Hybond $\mathrm{N}^{+}$, Amersham). The membranes were hybridized with a DNA probe radioactively labeled with ${ }^{32} \mathrm{P} \alpha$-dCTP using a random-priming kit (Amersham). The labeling reaction and hybridization conditions followed the recommendations of the manufacturer. The probes contained either the CP gene of PRSV or the CP-ORF 3ORF4 of PapMV. Infected plants with PRSV and PapMV were used as positive controls, and healthy plants were used as negative controls.

Sequence analysis. The nucleotide sequences of the cloned amplified cDNA fragments resulting from the RT-PCR reactions had lengths of 1,063 bp and 1,080 bp for PRSV and PapMV, respectively. These sequences were compared with those available from the National Center of Biotechnology Information (NCBI) to confirm their identities. The starting point of the $\mathrm{CP}$ cistron was determined using MegAlign (version 3.03, DNASTAR) (40). Nucleotide and amino acid sequence alignments were generated using the Clustal W (1.6) algorithms of Clustal X (1.62b) with the default values of multiple alignment parameters; in particular, the Gonnet protein weight matrix was used for multiple alignment of amino acid sequences. Neighbor-joining cluster analysis of the pairwise distance matrix was used to generate unrooted trees of the relationships between the 36 complete $\mathrm{CP}$ sequences and, in a separate analysis, of their $\mathrm{N}$ terminal ends (ca. 114 to 116 residues). The data set of each of these two trees was bootstrapped 1,000 times using Clustal X to determine the majority-rule consensus trees based on bootstrap proportion values. The program "njplot" (unrooted) was used for drawing the trees.

\section{RESULTS}

Distribution of PRSV and PapMV in Mexico. The planning of the geographical survey for the presence of PRSV and PapMV was based, in part, on the relative importance of the papaya-producing regions (Table 1, Fig. 1). Samples were collected from representative localities thereof (Table 2). The papaya production

Table 1. Percent area planted to papaya and percent papaya production in the 15 Mexican states sampled for the presence of Papaya ringspot virus (PRSV) and Papaya mosaic virus (PapMV) $(43,44)$

\begin{tabular}{|c|c|c|c|c|c|}
\hline \multirow[b]{2}{*}{ State } & \multirow[b]{2}{*}{ Abbr.c } & \multicolumn{2}{|c|}{$\%$ Area planted $^{\mathrm{a}}$} & \multicolumn{2}{|c|}{$\%$ Production ${ }^{b}$} \\
\hline & & $1980-2003^{d}$ & 2004 & $1980-2003^{d}$ & 2004 \\
\hline Campeche & CAM & 0.5 & 1.2 & 0.3 & 0.4 \\
\hline Chiapas & CHIS & 2.4 & 12.4 & 4.5 & 23.7 \\
\hline Colima & $\mathrm{COL}$ & 0.9 & 2.1 & 0.6 & 2.3 \\
\hline Guerrero & GRO & 11.0 & 4.6 & 13.3 & 5.4 \\
\hline Jalisco & JAL & 3.1 & 2.6 & 3.5 & 2.5 \\
\hline Michoacán & $\mathrm{MICH}$ & 7.0 & 5.6 & 7.3 & 4.6 \\
\hline Nayarit & NAY & 2.3 & 3.6 & 2.2 & 1.2 \\
\hline Oaxaca & OAX & 7.6 & 5.2 & 9.0 & 9.3 \\
\hline Quintana Roo & $\mathrm{QR}$ & 0.7 & 1.4 & 0.6 & 1.9 \\
\hline Sinaloa & SIN & 1.0 & 1.5 & 1.0 & 1.6 \\
\hline San Luis Potosí & SLP & 6.5 & 2.3 & 2.1 & 1.6 \\
\hline Tabasco & TAB & 2.2 & 9.7 & 2.1 & 6.2 \\
\hline Tamaulipas & TAMS & 1.1 & 1.4 & 0.8 & 0.4 \\
\hline Veracruz & VER & 48.8 & 39.1 & 47.6 & 29.0 \\
\hline \multirow[t]{2}{*}{ Yucatán } & YUC & 2.5 & 6.2 & 3.2 & 9.2 \\
\hline & Totals & 97.6 & 98.9 & 98.1 & 99.2 \\
\hline
\end{tabular}

\footnotetext{
${ }^{a}$ As a reference, total area planted in 2004 was 23,900 ha.

${ }^{\mathrm{b}}$ As a reference, total production in 2004 was 781,078 metric tons.

${ }^{c}$ Official federal state name abbreviation.

${ }^{d}$ Mean value for representative years 1980, 1985, 1990, 1995, 2000, and 2003.
} 
Table 2. Summary of Papaya ringspot virus (PRSV) and Papaya mosaic virus (PapMV) isolate collection data from host papaya in 15 federal states of Mexico

\begin{tabular}{|c|c|c|c|c|c|c|c|c|c|}
\hline $\begin{array}{l}\text { Federal } \\
\text { state }^{\mathbf{a}}\end{array}$ & Region $^{\mathbf{b}}$ & County & $\begin{array}{l}\text { Samples } \\
\text { analyzed }\end{array}$ & $\begin{array}{c}\text { PRSV } \\
\text { positive }^{\mathbf{c}}\end{array}$ & $\begin{array}{l}\text { PapMV } \\
\text { positive }^{\mathbf{c}}\end{array}$ & $\begin{array}{c}\text { Mixed } \\
\text { infection }^{d}\end{array}$ & $\begin{array}{c}\text { Map } \\
\text { label }^{\mathrm{e}}\end{array}$ & $\begin{array}{c}\text { Sequenced isolate } \\
\text { acronym }\end{array}$ & $\begin{array}{c}\text { GenBank } \\
\text { accession no. }\end{array}$ \\
\hline \multirow[t]{2}{*}{$\overline{\mathrm{CAM}}$} & R10 & Campeche & 17 & 8 & 11 & 4 & 16 & & \\
\hline & & Holpechén & 5 & 2 & 4 & 2 & 17 & & \\
\hline \multirow[t]{8}{*}{ CHIS } & R1 & Escuintla & 3 & 0 & 0 & 0 & - & & \\
\hline & & Huixtla & 1 & 0 & 0 & 0 & - & & \\
\hline & & Mepastepec & 1 & 0 & 0 & 0 & - & & \\
\hline & & Pichucalco & 1 & 0 & 0 & 0 & - & & \\
\hline & & Puerto Madero & 1 & 1 & 0 & 0 & 12 & & \\
\hline & & Tapachula & 12 & 9 & 1 & 1 & 12 & CHIS8 & AF319500 \\
\hline & & & & & & & & CHIS22 & AJ012650 \\
\hline & & & & & & & & CHIS18 & AY017190 \\
\hline COL & R11 & Colima & 1 & 1 & 0 & 0 & 4 & COL1 & AF309968 \\
\hline \multirow[t]{5}{*}{ GRO } & R11 & Acapulco & 1 & 0 & 0 & 0 & - & & \\
\hline & & Coyuca de Benítez & 1 & 1 & 0 & 0 & 7 & GRO1 & AY017189 \\
\hline & & Cuajinicuilapa & 1 & 0 & 0 & 0 & - & & \\
\hline & & Sn. Marcos & 1 & 1 & 0 & 0 & 8 & & \\
\hline & & Tecpan & 2 & 2 & 0 & 0 & 6 & & \\
\hline \multirow[t]{3}{*}{ JAL } & R11 & Tomatlán & 16 & 12 & 0 & 0 & 3 & JAL15 & AF319482 \\
\hline & & & & & & & & JAL1 & AF319484 \\
\hline & & & & & & & & JAL3 & AF319483 \\
\hline \multirow[t]{2}{*}{$\mathrm{MICH}$} & $\mathrm{R} 2$ & Francisco J. Mugica & 8 & 8 & 2 & 2 & 5 & MICH3 & AF319485 \\
\hline & & & & & & & & MICH6 & AF319486 \\
\hline NAY & R6 & Tepic & 1 & 1 & 0 & 0 & 2 & NAY1 & AF319487 \\
\hline \multirow[t]{6}{*}{ OAX } & R11 & Ixtaltepec & 2 & 0 & 0 & 0 & - & & \\
\hline & & Sn. Pedro Mixtepec & 5 & 5 & 0 & 0 & 11 & & \\
\hline & & Soledad-Río Grande & 4 & 1 & 0 & 0 & 10 & & \\
\hline & & Tututepec & 11 & 9 & 0 & 0 & 9 & OAX19 & AF319488 \\
\hline & & & & & & & & OAX20 & AF319490 \\
\hline & & & & & & & & OAX24 & AF319489 \\
\hline \multirow[t]{2}{*}{ QR } & $\mathrm{R} 10$ & Felipe Carrillo Puerto & 10 & 5 & 6 & 3 & 13 & QR7 & AF319492 \\
\hline & & & & & & & & QR8 & AF319493 \\
\hline SLP & $\mathrm{R} 4$ & Ciudad Fernández & 2 & 2 & 1 & 1 & 36 & & \\
\hline & & Ebano & 4 & 3 & 0 & 0 & 38 & & \\
\hline & & Tamuín & 2 & 2 & 0 & 0 & 37 & SLP8 & AF319502 \\
\hline SIN & R6 & Guasave & 2 & 2 & 2 & 2 & 1 & & \\
\hline TAB & R5 & Comalcalco & 2 & 2 & 0 & 0 & 19 & TAB1 & AF319503 \\
\hline & & Huimanguillo & 43 & 25 & 1 & 1 & 20 & TAB2 & AF319504 \\
\hline & & Teapa & 4 & 1 & 0 & 0 & 18 & & \\
\hline TAMS & R4 & Aldama & 4 & 2 & 0 & 0 & 40 & & \\
\hline & & Altamira & 3 & 0 & 0 & 0 & - & & \\
\hline & & Ciudad Mante & 2 & 1 & 2 & 1 & 39 & TAMS8 & AF319494 \\
\hline & & Llera de Canales & 4 & 4 & 0 & 0 & 41 & TAMS 12 & AF319495 \\
\hline VER & $\mathrm{R} 2$ & Actopan & 3 & 3 & 0 & 0 & 28 & & \\
\hline & & Gutiérrez Zamora & 1 & 1 & 0 & 0 & 30 & VER33 & AF319498 \\
\hline & R4 & Alamo & 2 & 2 & 0 & 0 & 33 & VER7 & AF319496 \\
\hline & & Cerro Azul & 1 & 1 & 0 & 0 & 35 & & \\
\hline & & Nautla & 2 & 2 & 0 & 0 & 29 & & \\
\hline & & Papantla & 1 & 1 & 0 & 0 & 31 & & \\
\hline & & Tecolutla & 1 & 0 & 0 & 0 & - & & \\
\hline & & Tihuatlan & 3 & 1 & 0 & 0 & 32 & & \\
\hline & & Tuxpan & 1 & 1 & 1 & 1 & 34 & & \\
\hline & & Uzuluama & 1 & 0 & 0 & 0 & . & & \\
\hline & R5 & Acayucan & 2 & 2 & 0 & 0 & 21 & VER2 & AF319505 \\
\hline & & Atoyac & 1 & 0 & 0 & 0 & - & & \\
\hline & & Cardel & 4 & 3 & 0 & 0 & 26 & & \\
\hline & & Catemaco & 1 & 1 & 0 & 0 & 22 & VER16 & AF319506 \\
\hline & & Cotaxtla & 24 & 18 & 2 & 2 & 25 & VER65 & AF319497 \\
\hline & & & & & & & & VER67 & AF319507 \\
\hline & & & & & & & & VER72 & DQ008446 \\
\hline & & & & & & & & VER73 & DQ008447 \\
\hline & & & & & & & & VER74 & DQ008448 \\
\hline & & & & & & & & VER75 & DQ008449 \\
\hline & & Medellín & 3 & 2 & 0 & 0 & 24 & & \\
\hline & & Paso de Ovejas & 2 & 2 & 0 & 0 & 26 & VER41 & AY231130 \\
\hline & & & & & & & & VER42 & AJ012099 \\
\hline & & Puente Nacional & 3 & 0 & 0 & 0 & 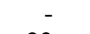 & & \\
\hline & & Tierra Blanca & 8 & 2 & 2 & 0 & 23 & VER51 & AJ012649 \\
\hline & R5-T & Tlilapan & 2 & 1 & 0 & 0 & 27 & & \\
\hline YUC & R10 & Mocochá & 1 & 0 & 0 & 0 & - & & \\
\hline & & Motul & 2 & 0 & 2 & 0 & - & & \\
\hline & & Oxkutzab & 1 & 0 & 1 & 0 & - & & \\
\hline & & Santa Elena & 2 & 1 & 1 & 0 & 15 & & \\
\hline & & Yobaín & 18 & 3 & 9 & 2 & 14 & YUC30 & AF319490 \\
\hline & & Grand total & 267 & 157 & 48 & 22 & & & \\
\hline
\end{tabular}

a Official state name acronym (see Table 1).

b Physiographic regions: R1 = Central American Mountain Range; R2 = Neovolcanic Axis; R3 = Great North American Plains; R4 = Northern Gulf Coastal

Plain; R5 = Southern Gulf Coastal Plain; R6 = Pacific Coastal Plain; R7 = Sonoran Plain; R10 = Peninsula of Yucatán; R11 = Southern Sierra Madre.

${ }^{c}$ Detected by reverse transcription-polymerase chain reaction (RT-PCR) and/or Northern blot analysis.

d Mixed infection with PRSV and PapMV.

e These labels are used in Figure 1. 
areas that account for more than $98 \%$ of the total yearly production fall into eight broad, distinct, physiographic regions shown in Figure 1. Plantations with variable levels of PRSV infection were found in all these regions. A significant proportion $(31 \%)$ of samples had no detectable infections in the data presented in Table 3. Broadly speaking, four types of putative PRSV symptoms were observed in the field: mosaic, mottling, leaf distortion, and necrotic areas (Table 3). Only PapMV was detected in addition to PRSV. Out of a total of 267 samples analyzed, 135 proved to be positive for the presence of PRSV and 48 for PapMV; the latter included 22 that were coinfected with PRSV (Tables 2 to 4 , Fig. 1). Five plants out of 26 with no symptoms (NS) tested positive for PRSV, one for PapMV, and none for mixed infections (Table 3). The data indicated slight differences in the geographic distribution of PRSV and PapMV. While PRSV was present in all 15 papaya-producing states, PapMV and mixed infections were only present in 10 (Fig. 1), but these differences did not follow any obvious geographical pattern. PapMV was more frequent (about $30 \%$ ) in the Gulf of Mexico than on the Pacific coast (about 20\%).

Except for a few collections of wild papaya samples in the southeast, no special effort was made to find specific kinds of papaya hosts. For the most part, the Cuban variety Maradol was clearly dominant in all the regions visited, although other varieties also occurred (Table 4). PRSV was present in all but the few wild papaya samples collected; PapMV was broadly detected except in 'Cera' samples.

Detection of PRSV in other feral or wild plant species. Of 27 samples collected from weedy species having viral symptoms, four were infected with PRSV and three with both PRSV and PapMV. The four samples infected only with PRSV occurred on three cucurbitaceous species: Cucurbita pepo var. cylindrica (calabacita or zucchini) and C. moschata (calabaza or pumpkin) from Yucatán (county labeled 14 on Fig. 1), and Citrullus lanatus from Michoacán (label 5, Fig. 1) (30); the other three samples, harboring both viruses, belonged in the Euphorbiaceae: Cnidoscolus chayamansa (Chaya or tree spinach) from Veracruz (label 25) and Quintana Roo (label 13). The 20 remaining samples, belonging to various families, tested negative for both viruses.

One of the two $C$. moschata samples from Yucatán was tested for its ability to infect papaya plants under greenhouse conditions. Leaf extracts produced very mild infection symptoms in papaya plants (only oily spots on the stem) and tested positive for PRSV by ELISA and Northern analysis. This provided evidence that these plants were carriers of PRSV type P.

Preliminary assessment of PRSV diversity. As part of a large evolutionary study of PRSV and coinfecting viruses such as PapMV, various sections of their genomes are being sequenced. The results of the first phase of the sequencing experiments are reported here. Our objective was to provide a rationale for this evolutionary study on the basis of the distribution of PRSV (and, as it happens, of PapMV), and the diversity in the amino acid sequence encoded in the CP cistron. Thus, the CP cistron of 36 PRSV isolates, from 20 locations representing all the geographical regions that were sampled, was sequenced (Table 2, Fig. 1). After identification of the beginning of the $\mathrm{CP}$ cistron, nucleotide sequences were determined and their identities compared with three previous isolates sequenced in this laboratory (45) and others published in GenBank. The 33 new CP sequences have been deposited in GenBank.

Analysis of all the PRSV Mexican CP sequences served as the basis for generation of the matrix containing all pairwise distances between sequences. Thus, the percent divergence within the group of 36 Mexican sequences varied from 9.9 to $0.4 \%$ (with a mean and standard deviation of $4.9 \pm 1.85 \%$ ). These data were then summarized by drawing the corresponding bootstrapped, majority-rule, neighborjoined (N-J) tree (Fig. 2A). Since no data are available that may indicate specific phylogenetic relationships among the sequences of the 36 Mexican isolates, we have limited the analysis to unrooted N-J trees. Five groups of sequences can be discerned in the unrooted tree of Figure $2 \mathrm{~A}$, which represents the clustering of the complete CP sequences of all isolates. Group 1A includes three stable subgroups of the sequences of isolates from the $\mathrm{Pa}$ cific coastal areas of the southeastern states of Chiapas, Oaxaca, Guerrero, and Michoacán; the high bootstrap proportions (BPs) at the nodes defining each subgroup indicate their high stability. Groups $2 \mathrm{~A}$ and $3 \mathrm{~A}$ include all but one accession (TAMS.12) from the Gulf coast. There is a mixed assortment of sequences from Veracruz in both groups: whereas group $2 \mathrm{~A}$ mostly contains sequences from only one location (Cotaxtla, labeled 25 in Table 2 and Fig. 1), 3A includes those from other locations and only one from Cotaxtla. The $\mathrm{BPs}$ of the nodes defining groups $2 \mathrm{~A}$ and $3 \mathrm{~A}$ are relatively low (less than $60 \%$ ), indicating that the majority-rule clustering for these sequences is somewhat loose. The remaining groups and accessions branch off the backbone with low BP values at the corresponding nodes. Group 4A contains all the sequences from Quintana Roo (Yucatán Peninsula). Group 5A contains those from Colima, Jalisco, and Nayarit, on the Western Pacific coast. Finally, two accessions, from Yucatán and Tamaulipas, branch out of the tree backbone, showing no specific position in relation to the groups described above.
The low BPs for the nodes defining each group called for a closer scrutiny of the multiple alignment data. Most of the variability was near the $\mathrm{N}$-terminus of the $\mathrm{CP}$ sequences. A second distance matrix was calculated for the alignment of the $\mathrm{N}$ terminal 114 to 116 amino acid residues of the $\mathrm{CP}$ of the 36 accessions (about $40 \%$ of the full length of each sequence). In this analysis, the percent sequence divergence within the group of 36 Mexican sequences varied from 18.4 to $0 \%$ (with a mean and standard deviation of $7.0 \pm 3.5 \%)$. The unrooted, majority-rule N-J tree of Figure 2B summarizes the results. As expected, the new distance matrix helped to consolidate some important clusters of sequences: the BPs increased significantly at key nodes, and the internode distances approximately doubled within and between some clusters (compare the scales of Fig. 2A and B). Six groups can be discerned, and their arrangement, composition, and stability differ from those of the previous analysis in significant ways. Firstly, group $1 \mathrm{~A}$ is now split into three stable clusters, groups $1 \mathrm{~B}, 4 \mathrm{~B}$, and $6 \mathrm{~B}$, in which the sequences from Chiapas, Oaxaca, Michoacán, and Guerrero are clearly set apart from each other (Fig. 1 and 2B). Secondly, groups $2 \mathrm{~B}$ and $3 \mathrm{~B}$ are still similar to $2 \mathrm{~A}$ and $3 \mathrm{~A}$ in that they contain roughly the same accessions, albeit with a different assortment into the two clusters. Possible explanations for these changes and the new placement of the sequences from Quintana Roo and Yucatán will be given in the discussion. Finally, group 5B remains essentially identical to $5 \mathrm{~A}$, but its stability has decreased, bringing it closer to the groups of the Gulf region.

Variation across physiographic regions. From the viewpoint of the broad physiographic regions shown in Figure 1, the distribution of $\mathrm{CP}$ sequence diversity takes another, more subtle, dimension. In the N-J trees of Figure 2, groups 1A or 1B, and $4 \mathrm{~B}$ and $6 \mathrm{~B}$, fall into the coastal plains and valleys of the two regions characterizing the Pacific southeast of the country: the Southern Sierra Madre (R11) and the Central American Mountain Range (R1; Fig. 1). The sequences from Chiapas in $R 1$ are clearly the most distinct of the whole data set, followed by those from Oaxaca and Guerrero. R1 and R11 are topographically separated by the Sierra Atravesada along the southern coastal edge of the Isthmus of Tehuantepec, the narrowest part of Mexico. Group 5A (or 5B) falls into the northern section of R11, 400 to $700 \mathrm{~km}$ northwest of the westernmost collection site in Guerrero (labeled 6 in Fig. 1). The coastal plains of the Southern Sierra Madre (R11) are extremely narrow, and mountains often meet the sea over most of its range, particularly in southern Michoacán. The collection site of isolate Nay.1 lies further north, on the southern tip of the Pacific Coastal Plains (R6). Group 4A, formed by 
the CP sequences of isolates from Quintana Roo, belongs in the Yucatan Peninsula (R10), a vast, low-lying region extending northeast from the Isthmus of Tehuantepec into the Gulf of Mexico and the Caribbean. Finally, groups $2 \mathrm{~A}$ and $3 \mathrm{~A}$ on the one hand, or $2 \mathrm{~B}$ and $3 \mathrm{~B}$, cover the Northern and Southern Gulf Plains (R4 and R5, respectively; Fig. 1). These extensive physiographic regions are separated by the western tip of the Neovolcanic Axis or Transmexican volcanic belt (R2 in Fig. 1).

\section{DISCUSSION}

PRSV and PapMV are present in all papaya production areas in Mexico. It was not until the early 1970 s that papaya producers became fully aware of the economic impact of PRSV infection. In 1975, PRSV was the first virus to be reported in papaya in Mexico (48). Our results show that this potyvirus is widespread throughout papaya plantations in this country, where it probably has a long history. The potexvirus PapMV was first reported in Mexico in 2001 (28), and it is highly likely that it is present in all production areas, although more intensive sampling in some of these will be required to firmly establish this hypothesis. We have also found both viruses in other weedy species, which suggests their role as sources of aphidtransmitted viruses. Since the production of papaya is continuous in most regions, these sources would cause chronic and recurrent infections in most plantations.

Presently, Maradol is the predominant papaya variety in commercial plantations throughout all production regions in Mexico. The occurrence of PRSV in papaya cultivars other than Maradol, such as land types Cera or Amameyada (also known as Roja), is therefore suggestive of the presence of the virus long before large-scale production of Maradol started in this country. The prevalence of PRSV in cultivated local types and feral populations of Carica papaya is yet to be ascertained. Inasmuch as our current knowledge of the adaptation and diversification of PRSV and PapMV to papaya as host in its center of origin is

Table 3. Symptoms observed in all papaya plants infected with only Papaya ringspot virus (PRSV), only Papaya mosaic virus (PapMV), or both viruses simultaneously

\begin{tabular}{lcccccc}
\hline Symptoms $^{\text {a }}$ & $\begin{array}{c}\text { Samples } \\
\text { analyzed }\end{array}$ & $\begin{array}{c}\text { Only } \\
\text { PRSV }\end{array}$ & $\begin{array}{c}\text { Only } \\
\text { PapMV }\end{array}$ & $\begin{array}{c}\text { Mixed } \\
\text { infection }\end{array}$ & $\begin{array}{c}\text { No virus } \\
\text { detected }\end{array}$ & $\begin{array}{c}\text { Relative } \\
\text { severity }^{\mathbf{c}}\end{array}$ \\
\hline An & 2 & 0 & 1 & 1 & 0 & 5 \\
Ld & 5 & 1 & 2 & 2 & 0 & 4 \\
Ms & 142 & 75 & 15 & 13 & 19 & 1 \\
Ms, An & 10 & 6 & 0 & 0 & 1 & 3 \\
Ms, Ld & 47 & 30 & 3 & 2 & 9 & 3 \\
Ms, Ld, Mt & 2 & 0 & 0 & 2 & 0 & 4 \\
Ms, Ld, Na & 4 & 1 & 1 & 0 & 2 & 5 \\
Ms, Mt & 6 & 4 & 1 & 0 & 0 & 4 \\
Ms, Na & 5 & 1 & 2 & 1 & 1 & 1 \\
Mt & 14 & 11 & 0 & 1 & 2 & 3 \\
Mt, Ld & 4 & 1 & 0 & 0 & 16 & 0 \\
NS & 26 & 5 & 1 & 0 & 53 & \\
Totals & 267 & 135 & 26 & 22 & & 2 \\
\hline
\end{tabular}

a An: apical necrosis; Ld: leaf distortion; Ms: mosaic; Mt: mottling; Na: necrotic areas; NS: no symptoms.

${ }^{\mathrm{b}}$ Mixed infections do not involve all the samples listed in columns 3 and 4.

${ }^{c}$ Scale based on visual observation where 5 is severe and 0 is no symptoms.

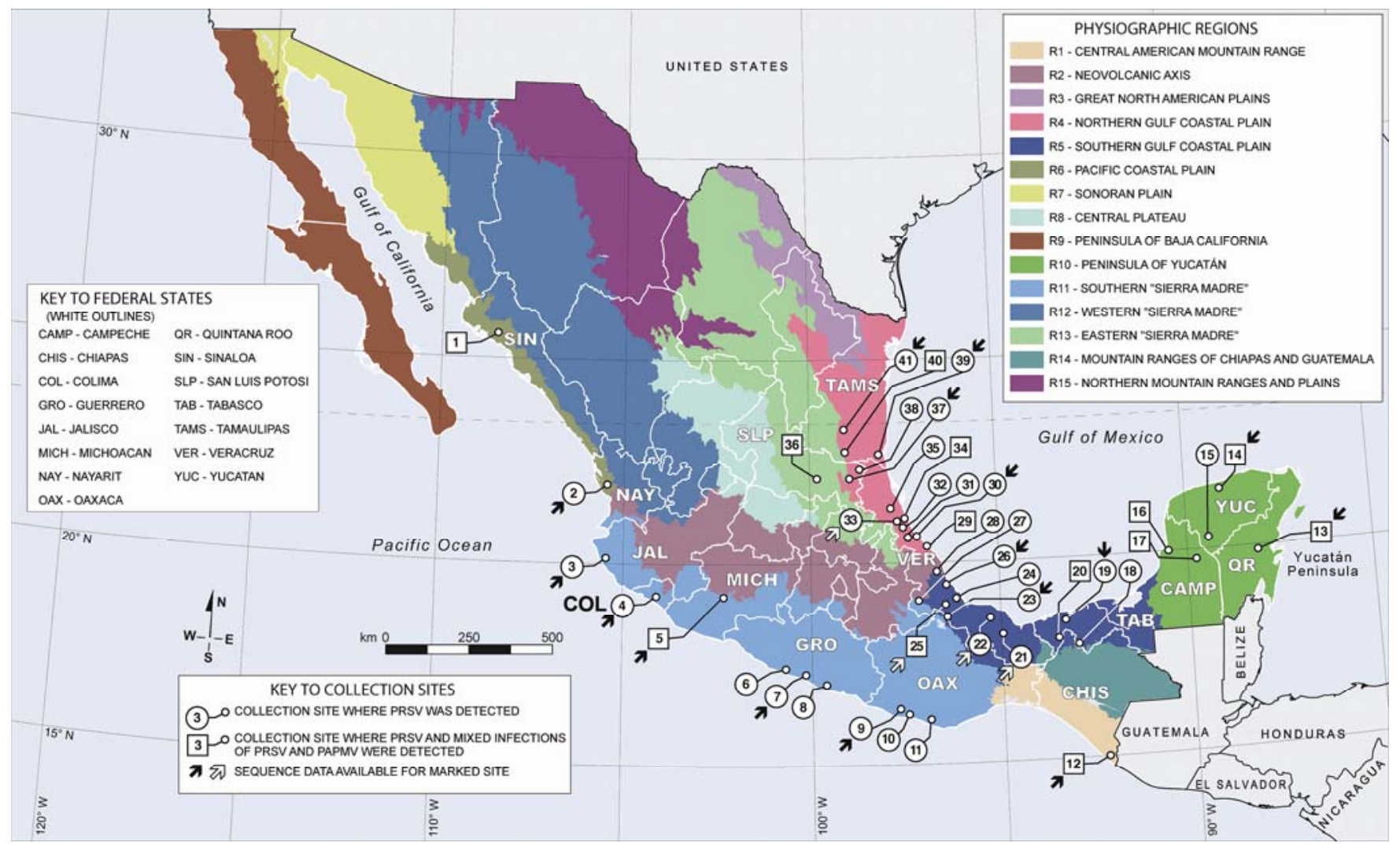

Fig. 1. Distribution of Papaya ringspot virus (PRSV, genus Potyvirus) and Papaya mosaic virus (PapMV, genus Potexvirus) in Mexico. Counties where leaf samples were collected are labeled with consecutive numbers (see Table 2); circular labels: PRSV; square labels: PRSV, PapMV, and mixed infections. Mapping of collection counties onto the political map is shown by white lines. Only the states of interest are labeled: Campeche (CAMP), Chiapas (CHIS), Colima (COL), Guerrero (GRO), Jalisco (JAL), Michoacán (MICH), Nayarit (NAY), Oaxaca (OAX), Quintana Roo (QR), Sinaloa (SIN), San Luis Potosí (SLP), Tabasco (TAB), Tamaulipas (TAMS), Veracruz (VER), Yucatán (YUC). Mapping of collection counties onto the physiographic map is shown by different colors (18). Data used for these maps are listed in Table 2. 
almost nonexistent, alternative hosts may play a very significant role.

Impact of alternate hosts and double infections. Our sampling, albeit limited, of putative alternate hosts in papaya fields or in the immediate vicinity indicated that they harbor both PRSV and PapMV (a potyvirus and a potexvirus), similarly to what has been described in other plant species. Our data established the widespread presence of mixed infections of PRSV and PapMV in papaya. We know of no other reports of mixed infections of these viruses in papaya plantations in Mexico or other parts of the world. Reservoirs of both viruses in double infections were also found in Cnidoscolus chayamansa (chaya mansa or tree spinach) from two southeastern locations, living in close vicinity of Maradol papaya plantations. The presence of weeds or feral species as reservoirs has been suggested before for other viruses and crops $(8,27)$.
CP sequence divergence in Mexican PRSV isolates. Of the studies describing the use of viral coat protein sequences for diversity surveys and taxonomic and phylogenetic studies $(2,3,19,34)$, the one by Bateson and coworkers provides a very thorough investigation of sequence variation in the CP sequences of 93 PRSV isolates in 13 countries (with particular emphasis on Thailand and Vietnam), from seven major continental or subcontinental regions of the world (3). The mean diver-

Table 4. Papaya ringspot virus (PRSV) and Papaya mosaic virus (PapMV) distribution in terms of the papaya varieties and types

\begin{tabular}{|c|c|c|c|c|c|c|c|}
\hline \multirow{2}{*}{$\begin{array}{l}\text { Papaya variety } \\
\text { or type }\end{array}$} & \multirow[b]{2}{*}{ Collection state(s) ${ }^{\mathbf{a}}$} & \multirow{2}{*}{$\begin{array}{c}\text { Samples } \\
\text { analyzed }\end{array}$} & \multicolumn{2}{|c|}{ PRSV } & \multicolumn{2}{|c|}{ PapMV } & \multirow{2}{*}{$\begin{array}{c}\text { Mixed } \\
\text { infection }\end{array}$} \\
\hline & & & Positive & (Negative) & Positive & (Negative) & \\
\hline Amameyada & CHIS, OAX, TAMS, YUC & 15 & 6 & (9) & 3 & (12) & 3 \\
\hline Cera & VER & 3 & 3 & 0 & 0 & (3) & 0 \\
\hline Criolla & VER, YUC & 7 & 2 & (5) & 2 & (5) & 0 \\
\hline Hybrids $^{\text {b }}$ & $\mathrm{TAB}$ & 26 & 20 & (6) & 1 & (25) & 1 \\
\hline Maradol & $\begin{array}{l}\text { CAMP, CHIS, COL, GRO, } \\
\text { JAL, MICH, NAY, OAX, } \\
\text { QR, SIN, SLP, TAB, } \\
\text { TAMS, VER, YUC }\end{array}$ & 209 & 126 & (83) & 40 & (169) & 18 \\
\hline \multirow[t]{2}{*}{ Wild (putative) ${ }^{\mathrm{c}}$} & CAMP, CHIS, YUC & 7 & 0 & (7) & 2 & (5) & 0 \\
\hline & Totals & 267 & 157 & $(110)$ & 48 & (219) & 22 \\
\hline
\end{tabular}

a Abbreviations defined in Table 1.

${ }^{\mathrm{b}}$ Hybrids between Amameyada and other local varieties such as Cera.

${ }^{c}$ Local names of putative wild papaya types were Chichput and Oreja de mico; the taxonomic identity of these papaya accessions remains uncertain, and it may be possible that these are specimens of the closely related, wild Jacaratia mexicana.

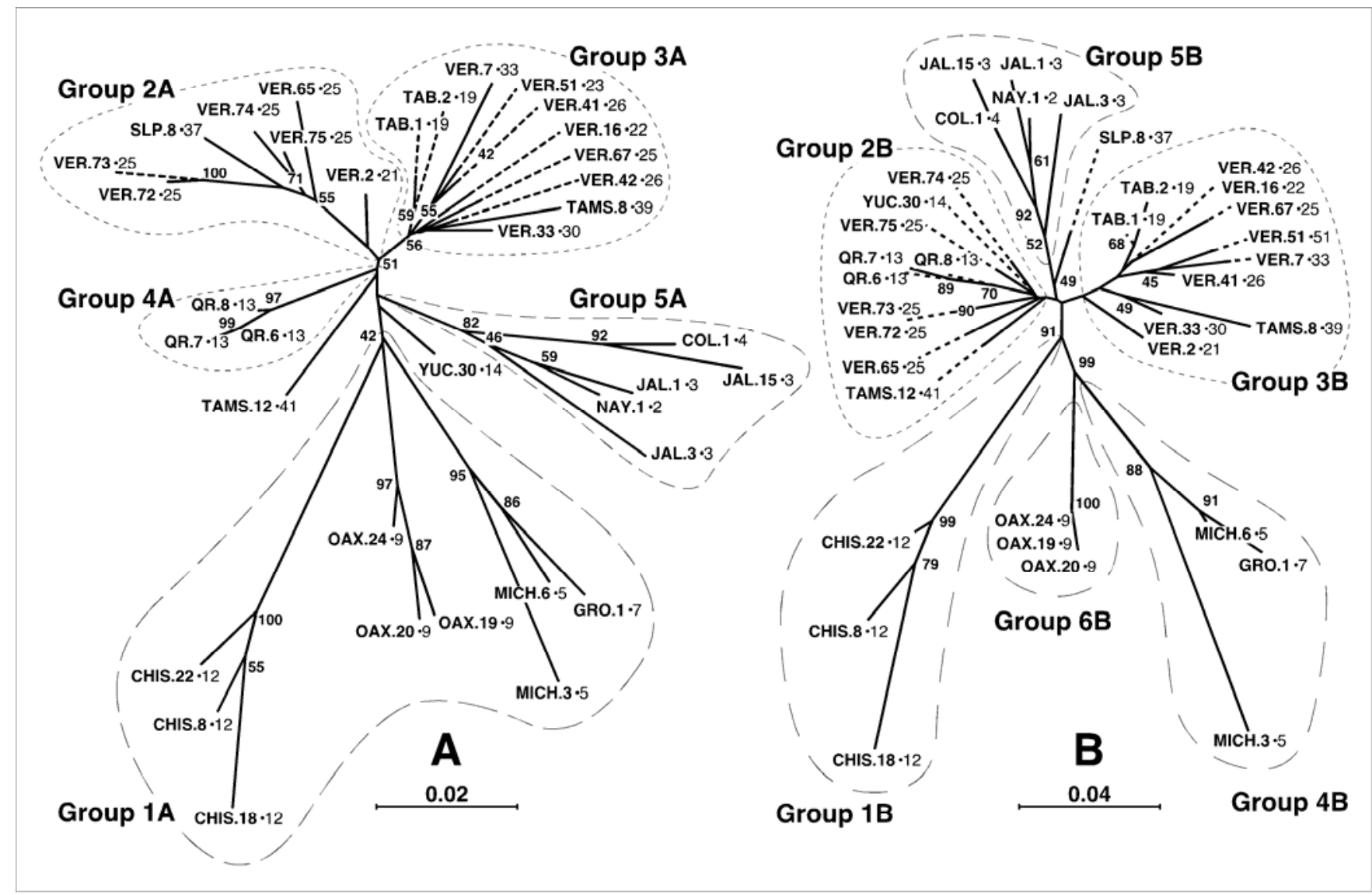

Fig. 2. Unrooted neighbor-joining (N-J) trees representing the coat protein (CP) sequence distances between 36 Mexican Papaya ringspot virus (PRSV) isolates after multiple alignment using Clustal W (1.6). When greater than 40\% (400/1,000), the percentage of bootstrap subtrees corresponding to particular nodes is shown next to those nodes. Each sequence is represented by the acronym of the corresponding PRSV isolate (Table 2) followed by the label for that collection on the map in Figure 1. Solid tree lines represent branch lengths; dashed balloons represent groupings discussed in the text. A, complete CP amino acid sequence; $\mathbf{B}, \mathrm{N}$-terminus of $\mathrm{CP}$ amino acid sequence (based on first 114 to 116 residues). 
gence between the $\mathrm{CP}$ amino acid sequences of the 36 PRSV Mexican isolates herewith reported $(4.9 \pm 1.9 \%)$ is about twice that found in Australia (2.2 $\pm 0.7 \%)$, is significantly higher than that found in Thailand $(2.8 \pm 1.3 \%)$, and is within the same range shown by the isolates from Vietnam $(4.0 \pm 2.8 \%)$. It is also lower than the worldwide mean sequence divergence calculated for all 93 isolates $(5.3 \pm 1.8 \%)$ but with overlapping variation ranges. These data values were extracted from Figure 2 of the published results of Bateson et al. (3).

A higher level of sequence diversity at the N-terminal end of the CP than in the rest of the protein has been described for PRSV and other potyviruses, which has been partly explained by variations in an $\mathrm{N}$-terminal region of EK repeats in the exposed structure of the CP (45). Moreover, the same region of the $\mathrm{CP}$ of sugar cane mosaic virus (SCMV) may exhibit "unexpected" variation patterns (29), and there is also evidence that various $\mathrm{N}$ terminus variations in different strains correlate with their host range (50). The high degree of diversity shown by the 36 Mexican CP sequence segments of ca. 116 amino acids at the N-terminal end, which was in all cases higher than for the complete protein, possibly reflects functional mutations associated with an increase in fitness of the virus populations in a region where host diversity is high. Indeed, papaya is very probably indigenous to southern Mexico (47), and although little is known about its genetic diversity in this region, it is likely higher than elsewhere. However, this seems in contradiction with the finding that all but four of the $36 \mathrm{se}$ quences included in this study belonged to isolates taken from the variety Maradol, which is probably very homogeneous throughout most of Mexico. This raises the intriguing question of whether the diversity of PRSV-P in Mexico, shown to be harbored by alternative hosts such as cucurbits and other species (e.g., Cnidoscolus chayamansa), is more a reflection of the diversity of these hosts $(12,13)$ than that of indigenous papayas. Moreover, thorough studies on the untapped sources of information about papaya and cucurbit genetic diversity in the southeastern regions of Mexico, available in back garden agricultural practices in small villages and farmers' homes, could help to clarify this matter $(5,17)$.

Diversity of Mexican PRSV isolates is correlated with their geographical origins. The information about physiographic partitioning of variation in our collection of isolates shows some very clear patterns. On the one hand, the most diverse PRSV isolates (Fig. 2) were collected from areas that tend to have more limited agricultural exchange with other regions, especially in terms of indigenous genetic resources (including local papaya types, cucurbits, and chaya mansa). This is the case of the Pacific coastal production areas and the Yucatán Peninsula (regions R1, R11, and R10 in Fig. 1B). On the other hand, the more heterogeneous structure of diversity (Fig. 2) in the coastal plains of the Gulf of Mexico (regions R4 and R5 in Fig. 1B) reflects on the higher economic development and more developed road systems that allow for extensive movement of papaya plants and other genetic resources. There is only one, relatively narrow, physiographic barrier in the middle of the state of Veracruz that has not affected the greater integration of regions R4 and R5. Thus, we find similar PRSV isolates in the very recently established small plantations in the northern state of Tamaulipas (labels 41 and 39 in Fig. 1), and in southeastern Veracruz (labels 22 to 26 in Fig. 1), which is also the oldest papaya production area. This observation suggests the likely importation of papaya plants from the latter region into Tamaulipas. Similar arguments can be used to explain the clustering of the isolate from the northern state of San Luis Potosí (label 37 in Fig. 1). Clear geographical patterns in other regions and countries of the world are not always as evident. In India, for example, there was no correlation between $\mathrm{CP}$ sequence divergence of 14 PRSV strains and their geographic origins (19). Similar conclusions were reached for isolates from southeast Asia and the Western Pacific, including Thailand, Vietnam, China, Japan, and the Philippines (3). However, geographical patterns at a continental level, in contrast to a regional level, could be deduced (Fig. 3 of the published results of Bateson et al. [3]).

This is the first report that describes the distribution of PRSV and PapMV in Mexico. We have shown that both of these viruses occur in single or mixed infections of papaya and other host species that could function as virus reservoirs. It is also the first report of the geographical diversity of PRSV in Mexico; furthermore, it establishes that this diversity is comparable to that found in other regions of the world and that, in contrast to most of those other regions, there is a clear correlation between $\mathrm{CP}$ sequence variation and the geographical origins of the virus isolates. As Bateson et al. have demonstrated for $\mathrm{CP}$ sequences of PRSV-W isolated from Thailand (3), the variation of the Mexican PRSV-P isolates indicates that there is a highly variable population of the virus in this region of the American continent where the virus has therefore had a long evolutionary history.

\section{ACKNOWLEDGMENTS}

We thank R. Tovar-Cortés and M. Ibarra-Cortés for cloning two PRSV isolates. We also appreciate the help of N. Becerra-Leor, W. Avilés, Ing. Sánchez, B. Aké, and R. Diaz-Plaza from various INIFAP stations in Mexico for selection of the papaya plantations for sampling and for sharing their knowledge of the papaya crop in Mexico. Thanks to John Délano-Frier for critically reading the manuscript. This research was partially funded by projects IFS D/2464-3, INIFAP-CONACyT (K0176), CONACyT (32568N), SEMARNAT/ 2002/CO1/304/A-1, and Fundación Produce Tabasco. J. C. Noa-Carrazana acknowledges financial support from Cinvestav and CONACyT (scholarship no. 111976).

\section{LITERATURE CITED}

1. Anjos, J. R., Jarlfors, U., and Ghabrial, S. A 1992. Soybean mosaic potyvirus enhances the titer of two comoviruses in dually infected soybean plants. Phytopathology 82:1022-1027.

2. Bateson, M. F., Henderson, J., Chaleeprom, W., Gibbs, A. J., and Dale, J. L. 1994. Papaya ringspot potyvirus: Isolate variability and the origin of PRSV type P (Australia). J. Gen. Virol. 75:3547-3553.

3. Bateson, M. F., Lines, R. E., Revill, P., Chaleeprom, W., Ha, C. V., Gibbs, A. J., and Dale, J. L. 2002. On the evolution and molecular epidemiology of the potyvirus Papaya ringspot virus. J. Gen. Virol. 83:2575-2585.

4. Chen, J., Zheng, H. Y., Chen, J. P., and Adams, M. J. 2002. Characterization of a potyvirus and a potexvirus from Chinese scallion. Arch. Virol. 147:683-693.

5. Cleveland, D. A., and Soleri, D. 1987. Household gardens as a development strategy. $\mathrm{Hu}-$ man Org. 46:259-270.

6. Conover, R. A. 1962 . Virus diseases of the papaya in Florida. Phytopathology 52:6.

7. Converse, R. H., and Martin, R. R. 1990. ELISA methods for plant viruses. Pages 179196 in: Serological Methods for Detection and Identification of Viral and Bacterial Plant Pathogens. R. Hampton, E. Ball, and S. De Boer, eds. American Phytopathological Society, St. Paul, MN

8. Csorba, R., Kiss, E. F., and Molnar, L. 2004 Reactions of some cucurbitaceous species to Zucchini yellow mosaic virus (ZYMV). Commun. Agric. Appl. Biol. Sci. 69:499-506.

9. Damirdagh, I. S., and Ross, A. F. 1967. A marked synergistic interaction of potato viruses $\mathrm{X}$ and $\mathrm{Y}$ in inoculated leaves of tobacco. Virology 31:296-307.

10. De Los Santos, F., Becerra, E. N., Mosqueda, R., Vasquéz, A., and Vargas, A. B. 1997. Manual de producción de papaya en el Estado de Veracruz. E. Pérez-Luna, ed. Vol. Folleto Técnico N ${ }^{\circ}$ 17/ División Agrícola. Cotaxtla, Veracruz, Mexico: INIFAP. Centro de Investigación Regional Golfo Centro.

11. Fauquet, C. M., Mayo, M. A., Maniloff, J. Desselberger, U., and Ball, L. A. 2005. Virus Taxonomy: Eighth Report of the International Committee on Taxonomy of Viruses, ICTV. Elsevier, San Diego.

12. Ferriol, M., Picó, B., Fernández de Córdova, P., and Nuez, F. 2004. Molecular diversity of a germplasm collection of squash (Cucurbita moschata) Determined by SRAP and AFLP Markers. Crop Sci. 44:653-664.

13. Ferriol, M., Pico, B., and Nuez, F. 2003. Genetic diversity of a germplasm collection of Cucurbita pepo using SRAP and AFLP markers. Theor. Appl. Genet. 107:271-282.

14. Goldberg, K.-B., and Brakke, M. K. 1987. Concentration of maize chlorotic mottle virus increased in mixed infections with maize dwarf mosaic virus, strain B. Phytopathology 77:162-167.

15. Gonsalves, D., and Ishii, M. 1980. Purification and serology of papaya ringspot virus. Phytopathology 70:1028-1032.

16. Gonsalves, D., and Trujillo, E. E. 1986. Tomato spotted wilt virus in papaya and detection of the virus by ELISA. Plant Dis. 70:501-506.

17. Hernández Xolocotzi, E. 1985. La agricultura en la Península de Yucatán. Pages 371-409 in: Xolocotzia - Obras de Efraím Hernández 
Xolocotzi. C. E. d. 1. R. d. G. Agrícola, eds. Universidad Autónoma de Chapingo, Chapingo, México.

18. INEGI. 1981. Carta Fisiográfica. S. P. P., ed. Mexico City.

19. Jain, R. K., Sharma, J., Sivakumar, A. S., Sharma, P. K., Byadgi, A. S., Verma, A. K., and Varma, A. 2004. Variability in the coat protein gene of Papaya ringspot virus isolates from multiple locations in India. Arch. Virol. 149:2435-2442.

20. Jensen, D. D. 1949. Papaya virus diseases with special reference to papaya ringspot. Phytopathology 39:191-211.

21. Koenig, R., and Lesemann, D. E. 1978. Potexvirus group. Commonw. Mycol. Inst. Assoc. Appl. Biol., Surrey, UK.

22. Lana, A. F. 1980. Transmission and properties of virus isolated from Carica papaya in Nigeria. J. Hortic. Sci. 55:191-197.

23. Lastra, R., and Quintero, E. 1981. Papaya apical necrosis, a new disease associated with a rhabdovirus. Plant Dis. 65:439-440.

24. Lindbo, J. A., and Dougherty, W. G. 1992. Untranslatable transcripts of the tobacco etch virus coat protein can interfere with tobacco etch virus replication in transgenic plants and protoplasts. Virology 189:725-733.

25. Maoka, T., Kashiwazaki, S., Tsuda, S., Usugi, T., and Hibino, H. 1996. Nucleotide sequence of the capsid protein gene of papaya leafdistortion mosaic potyvirus. Arch. Virol. 141:197-204.

26. Mclean, D. M., and Olson, E. O. 1962. Symptoms of tobacco ringspot virus on papaya. Plant Dis. Rep. 46:882.

27. Nebreda, M., Moreno, A., Perez, N., Palacios, I., Seco-Fernandez, V., and Fereres, A. 2004. Activity of aphids associated with lettuce and broccoli in Spain and their efficiency as vectors of Lettuce mosaic virus. Virus Res. 100:83-88.

28. Noa-Carrazana, J. C., and Silva-Rosales, L. 2001. First report of a Mexican isolate of Papaya mosaic virus in Papaya (Carica papaya) and pumpkin (Cucurbita pepo). Plant Dis. 85:558.

29. Oertel, U., Schubert, J., and Fuchs, E. 1997. Sequence comparison of the 3 '-terminal parts of the RNA of four German isolates of sugarcane mosaic potyvirus (SCMV). Arch. Virol. 142:675-687.

30. Paris, H. S. 1989. Historical records, origins, and development of the edible cultivar groups of Cucurbita pepo (Cucurbitaceae). Econ. Bot. 43:423-443.

31. Pruss, G., Ge, X., Shi, X. M., Carrington, J. C., and Vance, V. B. 1997. Plant viral synergism: The potyviral genome encodes a broad-range pathogenicity enhancer that transactivates replication of heterologous viruses. Plant Cell 9:859-868.

32. Purcifull, D. E., Edwardson, J., Hiebert, E., and Gonsalves, D. 1984. Papaya ringspot virus. Descriptions of Plant Viruses. Commonw. Mycol. Inst. Assoc. Appl. Biol., Surrey, UK.

33. Purcifull, D. E., and Hiebert, E. 1971. Papaya mosaic virus. Descriptions of Plant Viruses. Commonw. Mycol. Inst. Assoc. Appl. Biol., Surrey, UK.

34. Quemada, H., L'Hostis, B., Gonsalves, D., Reardon, I. M., Heinrikson, R., Hiebert, E. L., Sieu, L. C., and Slightom, J. L. 1990. The nucleotide sequences of the 3 '-terminal regions of papaya ringspot virus strains $\mathrm{W}$ and $\mathrm{P}$. J. Gen. Virol. 71:203-210.

35. Rajapakse, R. H., and Herath, H. M. 1981. Vectors of the papaya virus in Sri Lanka. Beitr. Trop. Landwirtsch Veterinaermed 19:359-361.

36. Rajapakse, R. H., and Herath, H. M. 1981. Host susceptibility of the papaya mosaic virus in Sri Lanka. Beitr. Trop. Landwirtsch Veterinaermed 19:429-432.

37. Rochow, W. F., and Ross, A. F. 1955. Virus multiplication in plants doubly infected by potato viruses $X$ and $Y$. Virology 1:10-27.

38. Rodríguez-Escobar, J. G. 1994. Distribución de las virosis en papaya en México. Tesis Maestro en Ciencias, Colegio de Posgraduados, Montecillo, México.

39. Ruiz-Castro, S., and Silva-Rosales, L. 1997. Use of RT-PCR for papaya ringspot virus detection in papaya (Carica papaya) plants from Veracruz, Tabasco and Chiapas. Rev. Mexicana Fitopatol. 15:83-87.

40. Saitou, N., and Nei, M. 1987. The neighborjoining method: A new method for reconstructing phylogenetic trees. Mol. Biol. Evol. 4:406425.

41. Scheets, K. 1998. Maize chlorotic mottle machlomovirus and wheat streak mosaic rymovirus concentrations increase in the synergistic disease corn lethal necrosis. Virology 242:28-38.

42. Shi, X. M., Miller, H., Verchot, J., Carrington, J. C., and Vance, V. B. 1997. Mutations in the region encoding the central domain of helper component-proteinase (HC-Pro) eliminate po- tato virus $\mathrm{X} /$ potyviral synergism. Virology 231:35-42.

43. SIAP. 2004. Anuario Estadístico de los Estados Unidos Mexicanos de 2002 y 2003. Vol. I - Por Cultivo. SIAP-SAGARPA, Mexico.

44. SIAP. 2004. Anuario Estadístico de los Estados Unidos Mexicanos de 2002 y 2003. Vol. II Por Estado. SIAP-SAGARPA, Mexico.

45. Silva-Rosales, L., Becerra-Leor, N., RuizCastro, S., Teliz-Ortiz, D., and Noa-Carrazana, J. C. 2000. Coat protein sequence comparisons of three Mexican isolates of papaya ringspot virus with other geographical isolates reveal a close relationship to American and Australian isolates. Arch. Virol. 145:835-843.

46. Sit, T. L., AbouHaidar, M. G., and Holi, S. 1989. Nucleotide sequence of papaya mosaic virus RNA. J. Gen. Virol. 70:2335-2331.

47. Storey, W. B. 1976. Papaya - Carica papaya (Caricaceae). Pages 21-24 in: Evolution of crop plants. N. W. Simmonds, ed. Longman, London.

48. Teliz, D., Mora, G., Nieto, D., Gonsalves, D. Garcia, E., Matheis, L., and Avila, C. 1991. La mancha anular del papayo en México. Rev. Mexicana Fitopatol. 9:64-68.

49. Vance, V. B., Berger, P. H., Carrington, J. C., Hunt, A. G., and Shi, X. M. 1995. 5' proximal potyviral sequences mediate potato virus $\mathrm{X} /$ potyviral synergistic disease in transgenic tobacco. Virology 206:583-590.

50. Xiao, X. W., Frenkel, M. J., Teakle, D. S., Ward, C. W., and Shukla, D. D. 1993. Sequence diversity in the surface-exposed amino-terminal region of the coat proteins of seven strains of sugarcane mosaic virus correlates with their host range. Arch. Virol. 132:399-408.

51. Yang, S., and Ravelonandro, M. 2002. Molecular studies of the synergistic interactions between plum pox virus HC-Pro protein and potato virus X. Arch. Virol. 147:2301-2312.

52. Yeh, S.-D., and Gonsalves, D. 1984. Evaluation of induced mutants of papaya ringspot virus for control by cross protection. Phytopathology 74:1086-1091.

53. Yeh, S.-D., Gonsalves, D., Wang, H.-L. Namba, R., and Chiu, R. J. 1988. Control of papaya ringspot virus by cross protection. Plant Dis. 72:375-380.

54. Yeh, S.-D., Jan, F. J., Chiang, C. H., Doong, T. J., Chen, M. C., Chung, P. H., and Bau, H. J. 1992. Complete nucleotide sequence and genetic organization of papaya ringspot virus RNA. J. Gen. Virol. 73:2531-2541. 